InOedia $\quad \begin{aligned} & \text { InMedia } \\ & \text { The French Journal of Media Studies }\end{aligned}$

4 | 2013

Exploring War Memories in American Documentaries

\title{
Documenting Virtual War
}

Calvin Fagan

\section{(2) OpenEdition}

\section{Journals}

Electronic version

URL: http://journals.openedition.org/inmedia/733

DOI: 10.4000/inmedia.733

ISSN: 2259-4728

\section{Publisher}

Center for Research on the English-Speaking World (CREW)

\section{Electronic reference}

Calvin Fagan, «Documenting Virtual War », InMedia [Online], 4 | 2013, Online since 18 November 2013, connection on 08 September 2020. URL : http://journals.openedition.org/inmedia/733 ; DOI : https:// doi.org/10.4000/inmedia.733

This text was automatically generated on 8 September 2020

(c) InMedia 


\title{
Documenting Virtual War
}

\author{
Calvin Fagan
}

New technologies of imitation and simulation as well as surveillance and speed had collapsed the geographical distance, chronological duration, the gap itself between the reality and virtuality of war. As the confusion of one for the other grows, we face the danger of a new kind of trauma without sight, drama without tragedy, where television wars and video war games blur together. ${ }^{1}$

1 This paper will consider the challenge posed to cinematic notions of documentary realism by the emergence of digital imaging technology. Clearly, this has been a key topic within film studies for many years now, with debates largely centred on the indexical capacities of analogue film versus the manipulability of the digital image. Yet, rather than rehashing the issues of digital media's permeation of the cinematic apparatus, I intend to approach the question from a somewhat different angle. By examining instead the mediation of warfare through digital interfaces (i.e. digital imaging with the military apparatus), I will explore the extent to which this can be considered a virtualisation of war, and subsequently consider the consequences that this may have for documentary notions of witnessing or the evidential recording of historical events.

2 It is important to note that military and cinematic imaging technologies are not mutually exclusive, as Paul Virilio (among others) has forcefully emphasised for almost thirty years now. Yet more recent works by Tim Lenoir, James Der Darian and Roger Stahl have demonstrated how military modes of imaging war are increasingly dependent upon collaborations with the gaming industry. Lenoir was among the first to highlight this trend, coining the term 'military-entertainment-complex' to denote the convergence of military simulators and video game graphics, from the collaboration between Sega and GE Aerospace through to the implementation of the Institute for 
Creative Technologies, specifically charged with developing hybrid modes of simulating war that are deployable in both military applications and gaming environments. ${ }^{2}$

Such projects are explored further in James Der Darian's Virtuous War, which charts how military modes of imaging war have evolved from the 'cinema[tic] techniques' 3 described by Virilio into a digital composite of 'computer simulation, media dissimulation, global surveillance and networked warfare. ${ }^{4}$ Focussing primarily upon simulated warfare environments such as the "Synthetic Theatre of War (STOW), a prototype of immersive virtual environments that could use overhead reconnaissance, satellite communications, and massive parallel computing to integrate virtual, live, and constructive simulations of war in real time, ${ }^{5}$ Der Darian notes how the deployment of such technologies for both preparative training and live, networked execution of warfare is beginning to erode the 'gap itself between the reality and virtuality of war.' Thus, as simulative war comes to resemble gaming to an ever-greater degree, Der Darian's work poses urgent questions regarding the collapse of distinctions between preparation/execution and the virtual/real of warfare.

4 This convergence of military imaging technologies with the virtual, CG environments of simulators and commercial video games has created what Roger Stahl terms an 'interactive war,' with media representations of war no longer inviting passive consumption but rather exhorting the viewer to interactivity as a 'virtual citizensoldier,' embedded within a discursive regime dominated by gaming as the 'primary interface governing the civic experience of war. ${ }^{77}$ As television news coverage begins to incorporate 'first person relationships with weapons' ${ }^{8}$ and games such as Kuma War 'attempt to re-create the television war in playable real-time, ${ }^{9}$ Stahl observes a fundamental 'shift in the locus of authorisation, a shift from propaganda per se to the integration of war into existent practices of consumption. ${ }^{10}$ This mode of immersive interactivity is fundamentally dependent upon the technological convergence highlighted by Lenoir and Der Darian. If, as Stahl notes, the weaponry interface of the AC130 Spectre gunship is technologically and perceptually indistinguishable in Pentagon-released war footage (replayed across news media outlets and archived on YouTube) and within the gameplay of the Call of Duty: Modern Warfare series, ${ }^{11}$ then it is precisely this ontological levelling-effect of digital convergence (particularly the specific technological collaboration between the military and gaming industry) that enables the interactive mode to connect with, or 'recreate,' the virtualised space of war as it is depicted in ostensibly non-fictional media sources.

5 Clearly, this has a somewhat disruptive effect upon the long-established complicity between the military and the film industry. Film once had a privileged position in the documenting of war, both in terms of photochemical indexicality and an invaluable, exclusive access to the battlefield and actual equipment of war; a relationship that was developed particularly through the newsreel and propaganda campaigns of WWI and WWII. Yet this claim to non-fictional authenticity has become rather precarious. If, as Brian Winston has argued, documentary authenticity is now read intertextually, ${ }_{12}$ rather than being an indexically determined 'formal quality of the text itself, ${ }^{13}$ documentary film is placed in a somewhat problematic position since the non-fictional images of contemporary warfare played out on television and Youtube now arguably bear a greater aesthetic resemblance to gaming than newsreel/documentary. As such, viewers may now be inclined to associate the playable drone interface of video games such as Modern Warfare, or the realistic apparatus of the military-sponsored America's 
Army with military authenticity, to a greater degree than the aesthetic of documentary film.

6 Thus the very process of digitalising the military apparatus poses a fundamentally new challenge to documentary filmmakers. In particular, the historical reliance upon the evidentiality of the profilmic field, which privileges embodied, localised human interaction, becomes distinctly problematic in this context. The advent of remotely operated drone strikes and potential developments of AI and robotics clearly indicate that embodied presence is gradually ceding precedence to screen-based mediation, collapsing geographical distance and virtualising the very space of war.

7 Very few contemporary war documentaries have genuinely evolved to incorporate such changes in the waging of warfare, with the majority of Iraq/Afghanistan documentaries still maintaining a classical vérité approach to documenting the grunt'seye view of war. This paper will critically examine the continued tenability of such modes, considering whether this form of witnessing can function as a critique of virtual warfare - in terms of demonstrating the unchanging human cost - or rather, whether it may instead lend credence and justification to what Der Darian terms the collapse of the 'reality and virtuality of war. ${ }^{14}$ Subsequently, I will explore to what extent the effects of digital convergence can be read in the proliferation of hybrid documentary/ fiction forms, such as Brian de Palma's emulation of diverse amateur/institutional digital aesthetics in Redacted (2007). Finally, I will present readings of two films that attempt to engage directly with the virtuality of contemporary warfare by documenting military simulations. Tony Gerber and Jesse Moss' Full Battle Rattle (2008) and Harun Farocki's Serious Games (2009-10) will be discussed both in terms of the unique contributions they make to evidencing such rarely seen technological processes of simulating war, and in terms of the adaptations of documentary form required to engage with the virtuality of digital modes of imaging warfare.

\section{The Embattled Realist Mode}

8 Many of the documentaries made in the immediate aftermath of the 2003 invasion of Iraq tended to employ a mixture of expert-opinion interviews, media dissimulation, and political rhetoric to critique (or support, albeit in fewer cases) the grounds for war - Fahrenheit 9/11 (Michael Moore, 2004) being perhaps the most prominent example. Yet the dominant mode of response to the war by documentary filmmakers, emerging particularly since 2005 and continuing throughout the war in Afghanistan, has been to employ the techniques of cinema vérité to closely follow the day-to-day experiences of a handful of military personnel throughout the course of a single deployment. Films such as The War Tapes (Deborah Scranton, 2006) and Gunner Palace (Petra Epperlein and Michael Tucker, 2004) have earned the sobriquet 'Grunt Docs'15 for their strict limitation of perspective to the immediate experiences of relatively low-ranking ground troops, typically eliding any wider perspective or argument regarding the strategy or indeed validity of the war. This sub-genre has a historical lineage that Patricia Aufderheide dates back to John Huston's Battle of San Pietro (1945) and Martin Barker identifies as having developed during Vietnam to denote 'ordinary soldiers... who do not have ideas or commitments beyond their situation. ${ }^{16}$ While its proliferation during the Iraq War is likely technologically-motivated, with the plethora of amateur video diaries by soldiers and embedded reporters even allowing documentary 
filmmakers to direct by proxy or simply edit together pre-existent material, the viability of this type of filmmaking as an evidential mode of documenting war is contestable.

9 A useful introduction to some of the critical issues surrounding this mode of filmmaking is provided by the 'War, Documentary and Iraq' dossier in a 2007 issue of Framework, in which articles by Charles Musser, Jane Gaines, and Patricia Aufderheide contributed to a debate over the relative merits of political rhetoric, vérité, and formal modernism as documentary responses to the war. Musser posits the vérité trend as a direct reaction against the competing truth claims of rhetorically argued documentaries such as Robert Greenwald's Uncovered: The Whole Truth About The Iraq War (2003), noting that the vérité mode appears to offer viewers 'a relatively direct, unpreconceived and non-ideological insight into the grunt's-eye view of the world ...[as the] basis for its truth value. ${ }^{17}$ Its limitation, in Musser's account, is that 'the "dark side" - the corruption and interrogation techniques that have turned the war into a nightmare - does not yield itself to the camera in this way. ${ }^{18}$

Gaines and Aufderheide present more polar opinions on the vérité war documentary. Gaines, attempting to construct a 'Leftist rapprochement with documentary realism, ${ }^{19}$ vehemently asserts that 'the real historical material world of and about the Iraq conflict is the gold standard' ${ }^{20}$ and searches for moments within these films during which an 'immediately analytic camera' reveals 'things coming unraveled, finding, for instance, the myth that occupiers are liberators exposed in the most ordinary moment.' ${ }^{21}$ Conversely, Aufderheide claims that 'new technologies do not really change the stories about soldiers in the field very much,' finding only the perpetuation of a voyeuristic thrill of skirting death, which she dismisses as 'emotional pornography.' She is particularly sceptical of the notion that this style is suited to political critique, claiming that its limitation of perspective and mode of audience engagement may instead 'quell debate. ${ }^{22}$

11 At issue with the vérité observational mode, then, is as much what this approach elides as what it actively contributes to the documenting of war. In the accounts of Musser and Aufderheide, the most significant omission is an engagement with the wider political context. Yet a closer reading of The War Tapes and Gunner Palace, two films generally figured as typical of the Iraq Grunt Doc mode, can demonstrate that in fact intermedial excerpts of news reports are essential to establishing the disjunctive political perspectives that comprise the terms of each film's political debate.

Scranton punctuates The War Tapes with television news reports at regular intervals, often with the films' subjects gathering to watch, as if to imply that their identification with the wider progress of the war is key to maintaining a sense of cohesion or structure to the seemingly random IED explosions and other attacks. The film also features a diegetic critique of the corrupt inefficacy of KBR/Halliburton, and a comicironic cut from the roadside dumping of septic waste (replete with a rainbow) to George W. Bush proclaiming 'a day of great hope for Iraqis.' There is, therefore a clear attempt to at least gesture toward a wider political context than what is diegetically captured by the subjects' cameras. Generally, though, these media extracts appear to function as an illusory 'truth' to be punctured by the vérité material, most frequently by undermining the notion of 'major conflict' being concluded by demonstrating how this statement 'conflicts with what we're seeing and dealing with every day.' Similarly, Gunner Palace layers non-diegetic radio reports over the soundtrack in order to provide 
the same sense of a wider media narrative, and also courts political opinions from its subjects through distinctly structured interviews.

However, while some indications of the overarching political context are made, the exclusive focus upon ground-level troops elides any clear portrayal of the militarytechnological context outside of these localised experiences. Neither film betrays any sense of the relationship of the troops depicted to other units, let alone the higherranking orchestration of networked warfare. Thus, I would suggest that the problematic elision within this group of Grunt Docs is not so much the wider political context as it is the technological context. The above accounts by Lenoir, Der Darian, and Stahl portray a fundamental technological evolution in the waging of war that is simply not commensurate with the stasis of the vérité mode, which portrays an experience of warfare largely unchanged since the Vietnam era. Both Musser and Aufderheide seem on the verge of identifying this issue, with the assertions that, respectively, vérité does not capture the 'dark side' of war, and that new technologies do not appear to have changed the soldiering experience. I would, however, tweak their arguments slightly to insist that, firstly, the 'dark side' connotes not only torture but also the broader process of virtually executed warfare (conceived through simulations and carried out without regard for local context), and secondly, that by 'new technologies', one incorporates not only the proliferation of handheld digital cameras among soldiers but also newer digital modes of mediating warfare (drone interfaces, satellite surveillance, etc.).

The issue is then somewhat clarified: the stylistic and aesthetic continuity of the vérite mode, which may have offered a novel degree of subjective intimacy during Vietnam, is perhaps no longer suited to engaging with the technological complexities of contemporary warfare. As a generic approach to documenting war, vérités strengths lie in the observation of subjective, localised experience and the demonstration of the ongoing human cost of warfare. I do not intend to minimise the significance of this, and The War Tapes in particular is admirable in its portrayal of the traumatic psychological after-effects of war for Moriarty and Bazzi's growing disaffection. Yet the question remains as to whether this humanist approach is capable of documenting the changing nature of warfare as ground-level, face-to-face interaction is gradually supplanted by the disembodiment of screen-based mediation. Indeed, the vérité focus on individual actions and values, and the notion that this grounded, humanist observation can provide access to a greater 'truth' than news media accounts is beginning to appear rather outmoded as digital technologies gradually supplant the reliance on embodied interaction in favour of mediated observation and remote action. As the dominant mode of documentary response to contemporary war then, vérité may problematically divert attention from such technological issues by representing warfare as largely unchanged since the Vietnam era. One could even argue that this form of documenting war lends a (perhaps inadvertent, yet problematic) sense of validation or authentication to practices of contemporary warfare, since such straightforwardly realist representations may counterbalance broader tendencies towards virtualising distanciation and simulative engagement.

15 This question becomes even more pressing in relation to the war in Afghanistan and disparate drone strikes around the Pakistan-Afghanistan border. The simple fact that no documentary filmmakers have as yet even attempted to depict the ongoing drone war indicates a glaring discrepancy between current documentary practice and the possibilities afforded by gaming. Given the convergence of military and gaming digital 
imaging technologies, drone warfare became almost instantaneously playable as (among other titles) Call of Duty: Modern Warfare 3, while filmmakers are still apparently struggling to conceive of ways to document the increasingly disparate, disembodied practices of postmodern LIC (Low Intensity Conflict) warfare.

In part, this absence is of course reinforced by the relative secrecy of CIA operated drone strikes, the locations of which are far more difficult for filmmakers to access than, for instance, the rather more visible urban battlefields of Iraq (particularly given the opportunities for embedding during the invasion). Yet, on the very margins of documentary practice, there are emergent signs of moving-image works attempting to engage with the issue of drones, which may suggest potential alternatives to vérité in depicting the wider military-technological context of contemporary warfare.

"America's New Air Force," a short video profile of the Creech Air Force Base in the Mojave desert produced for CBS' 60 Minutes series, sketches a basic and rather innocuous portrait of drone warfare primarily through interviews with drone operators working on the site. While the interviews do not facilitate any serious debate over the use of drones and declassified excerpts of drone imaging from actual missions are presented entirely in isolation from local context, there is nonetheless one brief scene that begins to articulate a visual grammar of drone warfare. This is a simple shot/reverse-shot depicting a drone view of the presenter and camera crew from above, followed by a ground level shot of the presenter gazing upward and seeing nothing but 'blue sky.' While it would be disingenuous to attribute any radical progress in imaging drone warfare to "America's New Air Force," this short scene does nonetheless provide a rare attempt to visually integrate drone and ground level imaging, revealing the fundamental imbalance of power between these perspectives that is inaugurated by the drone's capacity to "see" while itself remaining invisible.

Furthermore, Omer Fast's Five Thousand Feet Is The Best, presented at the Venice Biennale and subsequently at the Imperial War Museum in London, offers perhaps the first rigorous audiovisual study of drone warfare. A looped 30-minute video installation that combines documentary, docudrama, and fictional tropes, Fast's film comprises two distinct but interweaved strands. In the first, Fast interviews a real former drone pilot whose identity is obscured, and whose recollections of military action, 'virtual stress,' and PTSD are predominantly presented in voiceover and juxtaposed with aerial tracking shots of suburban New England and the Las Vegas strip. The second strand features a scripted "interview" with an actor portraying a drone pilot, who strenuously digresses from Fast's questions ('What is the difference between you and someone who sits in an airplane?') to instead launch narrated docudrama-style tales whose only relevance to drones is (as the interviewee puts it) the 'moral' imperative to 'keep your work life and your domestic life separate.'

Five Thousand Feet does not contain any actual documentary footage of drone warfare, yet the film poetically revolves around this absence, evocatively juxtaposing (for instance) an anecdote about the importance of heat signatures in detecting buried IEDs with the glaring lights of the Las Vegas skyline. Through such juxtapositions, the thematic recurrence of PTSD, and the peculiar bleeding in the fictional pilot's final tale between details of civilian and military life, ${ }^{23}$ the film consistently blurs the boundaries between war zones and domesticity, between documentary and fiction, and ultimately, between virtual and embodied presence. As such, Fast's film, while certainly not strictly classifiable as documentary, nonetheless demonstrates a highly inventive approach to 
reconfiguring documentary tropes for the depiction of drone warfare, progressively moving beyond the stasis of the vérité mode to evoke the complex virtuality of contemporary military technologies.

\section{The Interstices of Documentary and Fiction}

If one examines the wider genre of war cinema for recent formal changes that may constitute a creative response or adaptation to the advent of the digital, perhaps the most noticeable trend is for blurring the boundaries between documentary and fiction. This is not entirely without historical analogue, since fiction films have incorporated war documentary footage at least as far back as D.W. Griffiths' Hearts of the World (1918), while 84 Charlie Mopic (Patrick Shane Duncan, 1989) borrowed the vérité documentary aesthetic wholesale for its fictional recreation of the Vietnam War. Yet there has certainly been an intensification of this trend, and a greater degree of nearunclassifiable hybridity, over the last ten years or so in (to give just a few examples): the combined use of actual military personnel and professional actors Battle for Haditha (Nick Broomfield, 2007) and Act of Valour (Mike McCoy and Scott Waugh, 2012); the use of journalistic source material in Green Zone (Paul Greengrass, 2010), In the Valley of Elah (Paul Haggis, 2007) and, somewhat more contentiously, Zero Dark Thirty (Kathryn Bigelow, 2012); and the simulation of a diverse range of non-fictional modes in Redacted (Brian de Palma, 2007). It would be rather simplistic and of doubtful value to posit any singular function for this hybridity in such a diverse group of films, which range from the bolstering of authenticity for ostensibly fictional films (Act of Valour being the extreme of this pole) to experimental docudrama approaches which simply liberate some of the more dogmatic conventions of documentary filmmaking.

21 Yet one could argue that, broadly, there seems to be an evolution of the documentary form, through which it is now regarded less as a privileged mode of indexical objectivity, and more as a fluid combination of generic tropes that are increasingly adaptable and potentially hybridised. This is clearly mirrored in current writing on documentary theory. Brian Winston, as noted earlier, has commented upon the ways in which the evidential claim of documentary objectivity has eroded, transforming notions of authenticity from indexicality to the realm of audience reception. The very act of reading authenticity intertextually would thus imply its fluidity and potential to evolve through new contexts and forms. Indeed, Stella Bruzzi's New Documentary defines the form as 'performative acts, inherently fluid and unstable, ${ }^{24}$ and observes how contemporary documentary filmmaking thas in various ways returned to its more relaxed roots with dramatisation, performance, and other forms of fictionalisation and narrativisation becoming once more predominant. ${ }^{25}$

However, both Bruzzi and Bill Nichols still appear to cling to a somewhat nostalgic notion of evidentiality, now relegated to the level of the "mere footage' 26 or 'the 'document' at its heart' ${ }^{27}$ that comprise the raw material which filmmakers, through creative interpretation, fashion into documentary itself. Nichols insists that such footage 'serves as empirical or factual evidence... [and] offers no perspective and has no voice, or a very faint one ${ }^{\prime 28}$ and even equates such 'documents (including photographs and archival footage)' with 'physical evidence such as fingerprints, hair or blood samples, DNA, and so forth' in a list of 'inartistic proof. ${ }^{29}$ Bruzzi's account of the 'document' allows for a greater degree of evidential indeterminacy, as she notes that it 
is 'infinitely accessible through interpretation and recontextualisation ... a mutable, not a constant, point of reference, ${ }^{30}$ yet there remains a hint of impartiality attached to the 'document' through the very act of its division from documentary proper.

Among the group of films listed above, perhaps the most formally radical and complexly hybridised - and thus most challenging to notions of the evidential document - is Brian de Palma's Redacted. The film's epigraph declares it to be 'inspired by an incident widely reported to have occurred in Iraq,' yet the film constantly straddles the boundaries of fiction and non-fiction, weaving together a range of ostensibly non-fictional aesthetic modes, from soldier's video diaries to television news reports, into a complex fictional whole.

As Martin Barker's reading of the film notes, de Palma's aesthetic is rooted in a carefully studied imitation of the wave of soldiers' video diaries uploaded to YouTube (prior to institutional restrictions on such practices) that 'created a recognisable look to the conflict. ${ }^{31}$ The primary issue with these YouTube diaries, in Barker's account, is 'the question of the trustworthiness of those images,' since he queries whether there can be 'authentic images when so much is clearly staged, posed and edited.' ${ }^{32}$

De Palma's simulation of the video diary aesthetic seems keenly aware of the performativity and perspective embedded in this footage. They are not merely present to lend the film's depiction of the Iraq War some vague sense of authenticity, but rather to explore how performativity and implicit perspective belie the associations of impartiality and evidentiality attached to such ostensibly non-fictional sources. Although many of the film's critics appear unconvinced as to the degree of realisteffect achieved by de Palma's imitation of the video diaries, I would argue that the heightened sense of performativity they contain is key to the film's innovative blurring of fictional and documentary forms and to the highlighting of their structured perspective and implicit audiences. The soldiers can be clearly seen negotiating the boundaries of generic, raucous barracks behaviour with the demands of their responsibilities to friends and family at home. Furthermore, the embedded news reports, particularly in the division between Western media ('CEN') and the Middle Eastern ('ATV'), betray a similar sense that documentary authenticity is performed, subject to the demands of a particular pre-determined audience interest.

By undermining notions of evidential impartiality, demonstrating the limitations of what the video diary, television news report, CCTV footage, etc. can offer in terms of structured meaning, and combining each of these elements into an innovative hybrid form which freely fictionalises around a reported but undocumented real event, de Palma's film is a fascinating example of the evolution of the documentary form for an era of digitised, virtualised war. Admittedly, Redacted's formal experimentation can only really be argued to engage with the virtuality of war in the sense of its permeation by media representations, rather than the virtuality resulting directly from its military-technological simulation. Nonetheless, the film's exemplary engagement of documentary/fiction hybridity and experimentation with intermediality at least evince an attempt to expand the boundaries of what film can achieve in capturing and performatively evidencing the interpenetration of contemporary war and digital media. 


\section{Documenting Virtual War}

27 This final section will present extended readings of two documentaries which have explicitly taken military simulations as their subject, and thus offer the most direct engagement with the high-tech virtuality of contemporary war as outlined by Lenoir, Der Darian, and Stahl. The two films under discussion are Full Battle Rattle, an otherwise fairly conventional documentary which focuses upon a military training simulation of Iraq set up in the US National Training Centre; and Harun Farocki's Serious Games, a series of documentary / video installation shorts, predominantly recorded in the Twentynine Palms Marine base and featuring CG (computer generated) simulations used for both training purposes and the treatment of PTSD.

Full Battle Rattle charts the progress of a US army battalion through immersive training scenarios in the simulated Iraqi town of Medina Wasl (created at the Fort Irwin National Training Centre, one of the locations covered in Virtuous War). The simulation - just one 'town' that is part of a larger, interconnected, simulation of Iraq - comprises role-playing Iraqi refugees as the local community, insurgents who plot to disrupt the battalion's missions in the town, and even a simulation of the media, who film and broadcast televised reports. This is combined with technological simulations of battle and injuries, using the MILES (Multiple Integrated Laser Engagement System) harness to record the outcomes of virtual combat with insurgents.

For this simulation to be effective as a training scenario, it clearly needs to be sufficiently immersive to induce the participants into behaving as though it were real, a point which is testified to within one of the film's interviews:

Everybody that arrives at the NTC knows that they're coming here for training. By the second or third day of the training that kind of disappears. The soldiers get into the reality of what they're doing, and even though they are out here in the middle of the Mojave desert, in a simulated Iraq, it gets real, and they get lost in the scenario.

31 The documentary thus offers, on one level, a portrait of subjects immersed in a simulated reality. In terms of its representation for the viewer, however, the film does not attempt to achieve a comparable mode of subjective immersion. Despite opening with a series of medium and long establishing shots which seem to locate the action in Iraq, followed by a burst of handheld, rapidly edited action sequences, the film shortly thereafter reorients the viewer as an off-screen voice yells "Everybody stop" and the seemingly dead and wounded rise to their feet. Beyond this brief but smart metafictional commentary on the capacity of film to create similarly immersive, simulated 'realities,' the film is otherwise structured through a somewhat conventional mix of direct-to-camera interviews interspersed with narrative developments of the scenario. As such, the viewer is basically precluded from the level of immersion demonstrated by the film's subjects.

In Mike Dillon's review of the film, he considers this a 'fail[ure] to pursue the implications of its own status regarding media's engagement with a war famously called "fictitious" by fellow documentarian Michael Moore in his incendiary 2003 Oscar speech,' arguing that it is ultimately 'uncommitted to any form of political commentary. ${ }^{33}$ Certainly, the veracity of the simulated Iraq afforded opportunities for the filmmakers to engage in a greater degree of formal or ontological play, perhaps 
through a more ambiguous and challenging blurring of the boundaries between real Iraq, simulated Iraq, and the complicity of film in virtualising such distinctions - an opportunity which is largely passed over in favour of more conventional documentary tropes which attempt to erect a critical distance from the simulation depicted. While the film is undoubtedly more interesting for its subject matter than any formal experimentation, it does nonetheless make a unique contribution to documenting the processes by which this simulation is constructed. By repeatedly cutting away from Medina Wasl to interviews with the architects of this simulation, Gerber/Moss are able to simultaneously document the immersion of the subjects and dissimulate the processes which contribute to the very structuring of the simulated Iraq.

33 Despite the lack of formal innovation though, the film still implicitly raises pertinent questions regarding how simulative training may translate rather unequivocally into the virtualised execution of war. This is particularly prominent in the film's ending, in which the town's gradual descent into anarchy is suddenly appeased with tentative promises of support for local construction projects and the subsequent relinquishing of power to local authorities. Viewed in the context of real events following the invasion of Iraq, this moment is highly evocative of fragility of peace in occupied Iraq. Der Darian's notion of the collapse in distinctions between preparation/execution and the virtual/real of warfare is here powerfully realised, as the simulations are revealed to be guided more by preconceived results than genuine response to local contexts.

34 Harun Farocki's Serious Games series of documentary / video installation shorts demonstrate a similarly direct engagement with the mediated virtuality of warfare. In the first instalment, Watson Is Down, Farocki presents a formal innovation which is central to the series' straddling of the virtual/real: a split-screen aesthetic, with one side embedded within the CG simulation of battlespace, and the other focussed upon the trainees as they communicate with other units and attempt to co-ordinate an effective strategy for networked warfare. This formal strategy solves, in the simplest manner possible, a perennial problem of documenting virtual war, since either of these two interconnected screens taken in isolation would appear rather insufficient. The former is essentially a filmed record of gameplay, dominated entirely by video game aesthetics and thus not necessarily 'filmic'; the latter consists solely of a recording of military personnel interacting with screens and would be dramatically rather flat without the parallel visualisation of the simulated environment. In the very act of splitscreen juxtaposition then, Farocki finds a formally effective method to informatively and dramatically document the waging of virtual, screen-mediated war, solving a problem that has clearly challenged many documentarists whose formal approaches are predicated upon the grounding of embodied interaction.

35 Watson Is Down thus provides a valuable insight into the current state of military simulative training procedures, whose significance in virtualising warfare is highlighted by Der Darian. Through the course of the film, Farocki demonstrates how software such as the Virtual Battle Space 2 program is used to co-ordinate networked warfare and instil controlled behavioural responses to the detection of threats, represented by the explosive devices and 'enemies' interjected into the scenario by the instructor.

36 Three Dead experiments with a different formal manner of juxtaposing the virtual and (apparently) real, in this case abandoning the split-screen aesthetic in favour of a dramatic cut between two versions of the same environment (one live action, one CG) 
in the middle of the film. The first section initially appears to be a plausible depiction of a small Iraqi town, but, much like Full Battle Rattle, is ultimately revealed as a live-action simulation taking place in the Marine Corps Air Ground Combat Centre at Twentynine Palms. The film depicts an incident of insurgency in a mosque which the trainee units must respond to. Subsequently, Farocki cuts to a CG version of this same terrain, traversed through a long aerial tracking shot and accompanied by a dramatic score. On the whole, Three Dead is rather short on contextualising detail, with the predominant emphasis placed upon the increasingly virtualising convergence of these forms as the aesthetic evolves from the cinematic to that of the digitised realm gaming and simulations.

Immersion, the longest and perhaps most interesting of the Serious Games shorts, reverts to the split-screen aesthetic to depict the use of CG simulations for the treatment of PTSD. One screen documents the recounting of a traumatic incident by a seemingly inexperienced recruit, sent on a first tour of Iraq, whose partner on a routine mission was killed by an unidentified explosion. This soldier is wearing a head-mounted display unit, the CG environment of which attempts to reconstruct the scene of the incident as accurately as possible and is depicted for the viewer on the left-hand side of the film's split screen. At several points during the recitation of the traumatic incident, the soldier appears on the verge of breakdown, reporting to the counsellor/instructor feelings of nausea and a high SUDS (glossed as Subjective Units of Disturbance Scale, rated between 0 and 100) rating of 80-90. This immaculately convincing performance comes to an abrupt conclusion as the applause of an undetected audience breaks out and the soldier removes his headset, casually joking that 'some of the nausea was real.'

38 Immersion thus perfectly demonstrates and encapsulates the layers of virtuality that insulate virtual war against the straightforward evidential mode of documentary filmmaking. The film's ending startles the viewer out of the passive consumption of this war story and invokes a heightened consciousness of the degree of performativity involved in the translation of real events into simulated reconstructions. Furthermore, this introduction of formal reflexivity invites the viewer to reflect further upon the technological virtualisation of war that takes place through both the "Virtual Reality Exposure for PTSD' program and the corresponding training applications. Implicit through each of these films, then, is a study of the ontological transformation of reallife events into $C G$ reconstructions and, in turn, realistic training simulations.

Both Farocki's Serious Games and Gerber/Moss' Full Battle Rattle can therefore be considered complementary ways of engaging the documentary form with what Der Darian terms 'virtual theory.' Der Darian distinguishes 'virtual theory' from both realist and idealist approaches to studying war, positing that 'world politics is also in need of a virtual theory that explores how reality is seen, framed, read, and generated in the conceptualisation and actualisation of the global event,' particularly through studying ways in which 'technical media constitute new virtual states of meaning and being. ${ }^{34}$ Serious Games and Full Battle Rattle are unique among contemporary documentary filmmaking in their attempts to directly engage with questions of virtuality, disembodiment, and performativity that permeate the simulative preparation and execution of recent wars. Furthermore, the formal innovations of Serious Games demonstrate a creative adaptation of the documentary mode and aesthetic, matching an incorporation of the intermediality of digital interfaces to the embodied, humanist grounding which has long been a strength of the war documentary. 
paper has explored various ways in which documentary film has responded to the challenges posed by digital media's virtualisation of contemporary warfare (as outlined in works by Tim Lenoir, James Der Darian, and Roger Stahl). I have argued that the cinema vérité mode employed in the majority of Iraq War documentaries may, contrary to many accounts which critique its perceived apoliticism, be problematic more for the elision of the wider technological context. Films such as The War Tapes and Gunner Palace maintain individual interaction as the locus of warfare, and thus serve to authenticate the embodied reality of contemporary wars despite the countervailing tendencies toward virtualisation and disembodiment. Posing the question of how the documentary form may adapt in order to engage with this virtual realm of simulation and high-tech mediation, I have explored the recent trend toward hybrid documentary/fiction modes, with a specific focus upon the ways in which Redacted's incorporation of digital media aesthetics represents an innovative attempt to stretch the boundaries of documentation and evidentiality. Finally, I have argued that Full Battle Rattle and Serious Games provide the most concerted effort among recent filmmaking to document the specific processes by which military simulations effect a virtualisation of war, offering the viewer a rare glimpse of the elements of networked warfare which are beginning to erode the military reliance upon embodied interaction and abstract war toward virtualised remote action.

\section{BIBLIOGRAPHY}

Aufderheide, Patricia. "Your Country, My Country: How Films About The Iraq War Construct Publics." Framework 48.2 (2007): 56-65.

Barker, Martin. A 'Toxic Genre': The Iraq War Films. London: Pluto Press, 2011.

Bruzzi, Stella. New Documentary. $2^{\text {nd }}$ Ed. London: Routledge, 2006.

Der Darian, James. Virtuous War: Mapping the Military-Industrial-Media-Entertainment Network. $2^{\text {nd }}$ Ed. Oxon: Routledge, 2009.

Dillon, Mike. “Full Battle Rattle (Review).” Film \& History 42.2 (2012): 118-122

Gaines, Jane. “The Production of Outrage: The Iraq War and the Radical Documentary Tradition.” Framework 48.2 (2007): 36-55.

Lenoir, Tim. "All but War is Simulation: The Military-Entertainment Complex." Configurations 8.3 (2000): 289-335.

Musser, Charles. "Film Truth in the Age of George W. Bush." Framework 48.2 (2007): 9-35.

Nichols, Bill. Introduction to Documentary. $2^{\text {nd }}$ Ed. Bloomington, Ind.: Indiana University Press, 2010.

Stahl, Roger. Militainment, Inc.: War, Media, and Popular Culture. Abingdon, Oxon: Routledge, 2010.

Virilio, Paul. War and Cinema: The Logistics of Perception. Trans. Patrick Camiller. London: Verso, 1989. 
Winston, Brian. Claiming the Real II: Documentary - Grierson and Beyond. London: BFI, 2008.

\section{Filmography}

“America's New Air Force,” 60 Minutes (CBS, 2009), http://www.cbsnews.com/video/watch/? id $=5245555 n$

Five Thousand Feet Is The Best (Omer Fast, 2011)

Full Battle Rattle (Tony Gerber and Jesse Moss, 2008)

Gunner Palace (Petra Epperlein and Michael Tucker, 2004)

Redacted (Brian de Palma, 2007)

Serious Games (Haroun Farocki, 2009-10)

The War Tapes (Deborah Scranton, 2006)

\section{NOTES}

1. James Der Darian, Virtuous War: Mapping the Military-Industrial-Media-Entertainment Network, $2^{\text {nd }}$ ed. (Oxon, UK: Routledge, 2009), 10.

2. Tim Lenoir, "All but War is Simulation: The Military Entertainment Complex," Configurations 8.3 (2000): 317; 328-34.

3. Paul Virilio, War and Cinema: The Logistics of Perception (London: Verso, 1989), 1.

4. Der Darian, Virtuous War, xx.

5. Der Darian, Virtuous War, 14.

6. Der Darian, Virtuous War, 10.

7. Roger Stahl, Militainment, Inc.: War, Media and Popular Culture (Abingdon, Oxon: Routledge, 2010), 18.

8. Stahl, Militainment, Inc., 42.

9. Stahl, Militainment, Inc., 92.

10. Stahl, Militainment, Inc., 138.

11. Stahl, Militainment, Inc., 101-3.

12. Brian Winston, Claiming the Real II: Documentary - Grierson and Beyond (London: BFI, 2008), 229.

13. Winston, Claiming the Real, 113.

14. Der Darian, Virtuous War, 10.

15. Patricia Aufderheide, "Your Country, My Country: How Films About The Iraq War Construct Publics," Framework 48.2 (2007), 59.

16. Martin Barker, A ‘Toxic Genre’: The Iraq War Films (London: Pluto Press, 2011), 66.

17. Charles Musser, "Film Truth in the Age of George W. Bush," Framework 48.2 (2007), 26.

18. Musser, "Film Truth," 30.

19. Jane Gaines, "The Production of Outrage: The Iraq War and the Radical Documentary Tradition," Framework 48.2 (2007), 41.

20. Gaines, "Production of Outrage," 46.

21. Gaines, "Production of Outrage," 47.

22. Aufderheide, "Your Country, My Country," 60-1.

23. This anecdote, which seemingly begins with a family vacation, takes on gradually darker hues as the family encounter a group of roadside construction workers. Through a disjunctive slippage in the narration, the workers' tools are transformed into weapons, and the entire group end up 
victims of a Hellfire missile launched from the drone that has apparently been observing them throughout.

24. Stella Bruzzi, New Documentary, $2^{\text {nd }}$ ed. (London, Routledge: 2006), 1.

25. Bruzzi, New Documentary, 8.

26. Bill Nichols, Introduction to Documentary, $2^{\text {nd }}$ ed. (Bloomington, Ind.: Indiana University Press, 2010), 75.

27. Bruzzi, New Documentary, 16.

28. Nichols, Introduction to Documentary, 125.

29. Nichols, Introduction to Documentary, 78.

30. Bruzzi, New Documentary, 26.

31. Barker, A 'Toxic Genre,' 36.

32. Barker, A 'Toxic Genre,' 36.

33. Mike Dillon, "Full Battle Rattle (Review)," Film \& History 42.2 (2012), 120.

34. Der Darian, Virtuous War, 220.

\section{ABSTRACTS}

This paper draws upon contemporary studies of military imaging to illustrate the shift in the execution of warfare from embodied human interaction toward the virtualising distanciation of technological mediation and remotely-operated, networked warfare. Considering the viability of a range of documentary forms for evidentially capturing this evolution, the author argues that the cinema vérité mode which dominated filmmakers' responses to the Iraq and Afghanistan wars - with its grounding in subjective, embodied experience - fails to engage with the wider technological context and perhaps problematically validates an unchanging, realist vision of war contrary to virtualising trends. Conversely, it is contended that the proliferation of hybrid documentary/fiction modes may constitute a creative adaptation to digital mediations of war, as exemplified by the formal and intermedial innovations of Redacted. Finally, two documentaries that specifically engage with military simulations - Tony Gerber/Jesse Moss' Full Battle Rattle (2008) and Harun Farocki's Serious Games (2009-10) - are extensively analysed in terms of their diegetic and formal contributions to documenting the technological virtualisation of war.

\section{INDEX}

Keywords: war, technology, documentary, digital media, simulation

\section{AUTHOR}

\section{CALVIN FAGAN}

Calvin Fagan is studying for a PhD in film studies at Queen Mary, University of London. His thesis project is entitled 'Digital Media and the Contemporary War Film: Virtuality, Embodiment, Immersion' and explores the use of digital military technologies in war cinema. Current research 
interests include the intersections of film, digital media, and military technology, particularly in terms of embodiment and machinic imaging. 